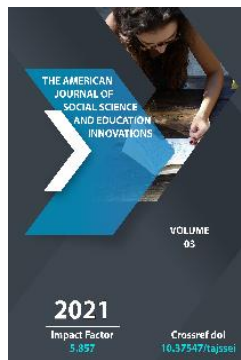

\title{
COVID-19 Pandemic: Problems Of Ensuring Gender Equality
}

\author{
Kamola Alieva \\ Senior Lecturer - Independent Researcher Of TSUL, Uzbekistan
}

Copyright: Original

content from this work may be used under the terms of the creative commons attributes 4.0 licence.

\section{ABSTRACT}

This article analyzes the issues of ensuring gender equality during the Covid19 pandemic in Uzbekistan and foreign countries. The author examines the reasons for the increasing digital gender inequality, the problem of women's access to work, women's domestic labor issues, and the global increase in domestic violence during the quarantine period. The author developed proposals for solving the above problems in order to solve the problem of increasing gender inequality during the period of a pandemic in the world and in Uzbekistan.

\section{KEYWORDS}

Covid19 pandemic, digital gender inequality, gender equality, domestic labor, women's access to work, domestic violence.

\section{INTRODUCTION}

The COVID-19 pandemic has caused inequality between states in all areas. The cause of the pandemic was huge differences between countries. This inequality has led to social crises in economically underdeveloped countries.
The decline in incomes has been noted not only in Uzbekistan[1], but all over the world, which has further complicated the daily lives of people living through external migration. 
Most notably, according to a UN study, the labor rights of female doctors and nurses and other medical staff working in medical facilities during COVID-19 were grossly violated. In the second case, they chose to become unemployed in the future, refusing to perform their labor activities due to pressure from men[2].

According to scientists, this period should be called a "pandemic of violence[3]." The reason for this was the sharp increase in the number of complaints of physical and psychological domestic violence and gender inequality during the pandemic.

Violations of consistency in the implementation of international aid and cooperation on a global scale have led to restrictions on economic, social and cultural rights in many countries, as well as serious disruptions in the uninterrupted supply of food and medicine to the population.

Against the background of COVID-19, inequality has intensified both within and between countries. The cause of the pandemic was huge differences between countries. The deepening of these inequalities and the unpreparedness of the health systems of underdeveloped countries to fight the pandemic could lead to other global pandemics.

The situation of women has worsened due to the 2020 coronavirus pandemic. According to the UN, the pandemic will put another 47 million women and girls below the poverty line[4]. The risk that the pandemic will not end in the world in 2021 also poses the risk[5] that these violence and economic hardships will be accompanied by a stronger wave.

This problem can have more serious consequences for women who face oppressive systems such as ethnicity, race, gender, age, economic class, and dependence. This in itself has led to a dramatic widening of the economic gap between women and men.

Experts estimate that by 2021 , there will be 118 women living in similar conditions for every 100 men aged 25 to 34 living in extreme poverty (less than two dollars a day). By 2030, that difference will exceed 121 women for every 100 men[6].

Therefore, one of the urgent tasks in the world community is to identify the features of the legal regulation of interpersonal violence and gender inequality in the context of a pandemic and to develop proposals and recommendations for their solution.

UN Secretary-General Antonio Guterres said in a speech to the General Assembly on the results of 2020 and the priorities for 2021: "We can leave Anus horribilis behind and turn this year into a year of annus possibilitatis opportunity and hope". In this report, UN Secretary-General Antonio Guterres highlighted the fight against gender inequality as the sixth of the UN's top 10 priorities[7].

At present, there are two approaches to the prevention of domestic violence in the world:

The first is conflict resolution, a restorative approach aimed at preserving the family;

The second is a punitive approach aimed at eliminating the period of violence by ending the relationship between the victim and the aggressor[8].

Analyzes show that in developed democracies, various liability measures are established for offenses related to domestic violence. There were also reports of women in special services being affected by the pandemic on the 
following key issues: domestic violence; intimidation in the cyber world; child marriage; sexual harassment and violence.

However, it is not advisable to identify gender equality issues only from calls to the call center. Given the national mindset of the peoples of Central Asia, it can be said that appealing to special authorities in cases of domestic violence is considered by the public to be contrary to family values formed over thousands of years.

In particular, according to a rapid gender assessment survey conducted by UN-Women in Kazakhstan, 15.3 percent of respondents reported hearing or experiencing an increase in domestic violence during the spread of COVID19. For comparison, cases of domestic violence during the quarantine period were reported by women aged 25-34 (16.6\%), divorced (22.8\%), and members of the socially vulnerable (22\%). However, more than $80 \%$ of the women surveyed during the COVID-19 period did not use maternity protection, family planning, or psychological support for victims of domestic violence[9].

According to a UN report dated April 6, 2020, the sharp increase in the number of women victims of male violence in the family is due to couples spending more time together during quarantine activities. In particular, while in France on March 17 (the day of the introduction of compulsory quarantine) domestic violence increased by 30\%, in Singapore and Cyprus we can see that the number of calls to hotlines on this issue increased by more than $30 \%$ [10].

As the COVID-19 pandemic has caused many problems of gender equality in a short period of time, many legal scholars, as well as sociologists, political scientists, economists and a number of other experts have put forward scientific hypotheses on the negative impact of the pandemic on gender equality and mitigation measures.

In a short period of time, a number of studies have been conducted about gender dimensions of the COVID-19 pandemic by de Paz C [11], The impact of COVID-19 on gender equality by Alon T. M. [12], Gender equality in work and Covid-19 deaths by Adams R. B. [13], Women's Copyright Infringement by PinhoGomes A. C. [14], Women's Increased Family Obligations by Power K. [15], Negative Impact on Women's Nutrition by Ragasa C., Lambrecht I. [16], The Impact of Women on Research Activity by Malisch J. L. [17], The Inequality of Men's and Women's Working Hours by Collins C. [18], The Question of the Responsibility of States by Fortier N. [19], Influence on Women's Education by d'Orville $\mathrm{H}$. [20], The Impact of Lockdown on Women's Rights in Germany by Czymara C. S., Langenkamp A., Cano T. [21], the impact of women on the scientific community, research activities by Gabster B. P. [22] Cui R., Ding H., Zhu F. [23], housing ownership and career issues by scholars such as Oleschuk $M$. [24].

The issue of domestic violence during the COVID-19 pandemic in the CIS countries was studied by A.S. Mjelskaya[25], The role of women in the economic life of Tajikistan by N.Ch. Abdurakhimova[26], Domestic violence in Uzbekistan by K.Alieva[27], Problems of women's health care system by N.S. Grudinin[28], the issues of practical application of constitutional principles on ensuring gender equality in criminal law in Russia by A.S. Mjelskaya[29], the issues of women's family labor by I.E. Kalabikhina, S.M. Rebrey[30].

As of January 4, 2019, India, Afghanistan, Syria, Somalia, Saudi Arabia, Pakistan, the 
Democratic Republic of the Congo, Oman, Nigeria and the United States are in the top 10 in terms of domestic violence results, according to Reuters[31].

In our view, one of the main factors threatening gender equality during the pandemic is the problem of domestic violence. The basic instinct of the patriarchal family, formed over thousands of years, is that men try to control a woman's actions, facial expressions, and inner experiences by force, limiting a woman's personal life and individual freedom. Scientists see the human right to be happy and free as an integral part of the right to life.

Therefore, based on the problems of gender equality during the pandemic period, it is expedient to separate domestic violence not only in relation to the use of physical force, but also in psychological, mental, economic, sexual, medical characteristics.

During the pandemic, it is proposed to digitize the current procedure for issuing protection orders to women and to reduce the 24-hour ordering period to 12 hours by studying the living conditions of the victim. This procedure provides that after consideration of the issue of the order by the inspector, the basic information on the protection order is automatically sent to the mobile phone of the spouse in the form of SMS-notification.

On August 20, 2020, the brutal beating and bodily injury of a wife by husband caused a public outcry on social media [32]. The woman was then issued a protection order. This situation has once again proved that women's disconnection from the means of communication can be a factor in the restriction of their rights.
According to Evsikov, the right to a means of communication is a constitutional right to receive and disseminate information[33].

According to $Z$. Khotkina, the old gender problems and the problems of developing the digital economy are related to the provision of women with digital technologies[34].

According to A. Gurumti, gender inequality related to the Internet is not only related to men's and women's access to the Internet, but also to the equality of opportunities for internet access models[35].

Studies show that low- and middle-income women use cell phones in 21\% fewer countries than men[36]. In Africa, the figure was 23\%, and in the Middle East it was 24\%. In addition, women living in urban areas own $23 \%$ more mobile phones than rural women.

Research on the use of the Internet by men and women has shown that men spend more time online than women. Women spend more time on social media, online shopping and email. In particular, women generally spend an average of five hours a week on social media, 36 minutes more per week than men, and young women between the ages of 16 and 20 - more than others. It is important to better understand how these trends differ between developing and developed countries, as they affect the impact of policies and programs.

In our opinion, governmental and nongovernmental non-profit organizations, as well as other institutions of civil society should ensure the inclusion of women in the information society. The period has proved that in a pandemic, the development of the digital economy can be done on the basis of Internet technologies. 
Therefore, in order to support women's entrepreneurship, it is proposed to develop a Concept for Improving Women's Internet Literacy.

In addition to the above considerations, it can be said that the use of the Internet in the search, reception, transmission, production and dissemination of information has changed the guarantees of the exercise of certain constitutional rights.

As an example of a pandemic situation, it should be noted that in the above case, the fact that a woman actually brought the problem to the social network caused a public resonance. Therefore, ensuring gender equality in a pandemic environment is a means of women's communication and the provision of internet access is a key factor in protecting women from violence.

Analyzes show that during the coronacrisis, there was a large-scale reduction of jobs in areas such as tourism infrastructure, catering and consumer services, as well as primary health care.

According to preliminary estimates, the share of women working in these areas is much higher than that of men. Therefore, 47 million of the 96 million people living in poverty by 2021 will be women, despite the fact that men are more likely than women to move across the country to find new jobs, have guaranteed jobs and adapt to remote jobs.

T. Narbaeva notes that many of our women go to labor exchanges and are not registered. If job fairs are announced, they will not go. More guys, men go there. Uzbek women are shy. Therefore, a door-to-door system of walk-in was established, i.e., professionals who work with women will be attached to us and to the neighborhoods[37].

Necessary measures have been taken to alleviate the difficult economic situation caused by women's unemployment caused by the pandemic and to ensure women's employment.

Uzbekistan has received \$ 100 million from the Fund for Reconstruction and Development. Of this, 10 million will be spent on vocational training, and 90 million will be spent on preferential loans for those who have completed training courses and received a certificate. Through the "Social Contract", young people and women graduating from non-governmental vocational training courses will receive a subsidy of up to 1 million soums for education[38].

In our opinion, in the context of a pandemic, it is advisable to provide women with skills in the first place in order to ensure their employment. In this regard, it is expedient to improve the practice of financing socially useful projects through targeted social ordering to nongovernmental non-profit organizations.

It is expedient to increase the number of public administration social projects for the employment of women in civil society institutions. At the same time, it is necessary to develop an open and transparent mechanism for the selection of social projects. It is necessary to establish a procedure for online broadcasting of projects through the Internet.

Governments in Canada, Germany, Spain, the United Kingdom, and the United States, women's rights activists, and civil society institutions have reported increased demand for domestic violence and emergency housing during the crisis. 
Resolution of the President of the Republic of Uzbekistan dated July 2, 2018 No 3827 "On measures to improve the system of social rehabilitation and adaptation, as well as prevention of domestic violence", "1146" helpline of Ministry of Mahalla and Family Support started operating[39].

The analysis shows that as of September 1, 2020, 197 centers have been established in Uzbekistan. According to the Republican Center, as of December 2019, more than 21 thousand applications were received. Of these, 986 were men, 788 were children and 19,874 [40] were women. As of October 1, 2020, 14,849 applications were received.

In our opinion, the fact that women are victims of domestic violence during the period of intensified quarantine measures has naturally made it necessary to reconsider the activities of rehabilitation and adaptation centers:

First, most of these types of centers are located far from populated areas. In some cases, victims are required to walk up to $70 \mathrm{~km}$ to reach the centers. Therefore, it is proposed to integrate the hotline number 1146 of the Ministry of Mahalla and Family Support with the number 1002 of the Ministry of Internal Affairs and the number 1003 of the ambulance. In doing so, depending on the nature of the problem, the shelter determines whether other specialized services should be consulted.

Second, based on the fact that by 2020, 168 men will also apply to these centers, it is proposed to develop and introduce special methods of providing legal and psychological assistance to men.

Third, family mediation can be widely introduced. It is advisable to involve clergy, psychologists, lawyers and economists as mediators, depending on the religious affiliation of the husband or wife. In the United States, for example, the institution of mediation in family disputes has been introduced. The Institute of Family Mediation is enshrined in Finnish law and is supported by the state not only as an institution for resolving family disputes, but also for resolving family disputes in general.

Therefore, professional mediators and their public associations are encouraged to be involved in the prevention of domestic violence by placing a state social order.

Government support for women affected by pandemics includes:

- Increase in social payments;

- Granting subsidies, grants, vouchers, soft loans;

- Delays in taxes and other mandatory payments;

- Simplification of conditions for receiving insurance payments (unemployment, social and health insurance) [41].

According to the Canadian experience, it provides comprehensive assistance to women and children affected by domestic violence during a pandemic. In particular, more than \$ 50 million has been allocated for this type of social service rehabilitation centers. At the same time, women from the local population will be given additional benefits to the centers that provide accommodation.

Despite tough measures by the Canadian government, more than 100,000 women have been victims of domestic violence, and the death toll has risen to 90 [42].

According to the Turkish experience, payments for loans and rents to women farmers in the 
agricultural sector have been suspended for 6 months, and 14 million square meters of state property have been given to a number of cities to grow certain types of products.

According to the Belgian experience, women were given the right to a Time credit, which provides for the reduction of an employee's working day or week or a temporary break in the workplace. There are different types of time loans:

- Regular;

- For certain specific reasons (for example, due to a pandemic);

- In connection with the termination of employment.

In addition, the amount of benefits for employees forced to retire due to force majeure was increased by $70 \%$.

In our opinion, according to the Belgian experience, it is expedient to establish a Public Fund under the auspices of the Federation of Trade Unions of Uzbekistan. At the same time, it is proposed to appoint a special pension from the public fund for women who have not reached the retirement age due to force majeure.

In general, in the prevention of all forms of violence against women, it is advisable to fully guarantee the right of women to appeal to the courts and other competent authorities. The main reason why women do not report less than $40 \%$ of cases of harm caused by domestic violence is that women do not trust the current system of gender equality [43].

In our view, in order to radically change the situation, it is necessary to learn how to detect domestic violence in legal education institutions, respond appropriately and how to combat discrimination in the light of pandemic conditions. This means collecting data to eliminate impunity and control their actions and the accountability of the authority through an effective regulatory procedure.

Equality, on the other hand, is a "one-size-fitsall" approach that ensures an equal distribution of resources. In the scientific community, female teachers face inequality. For example, women are involved in providing more services in the scientific field. They found that women were more likely to be discriminated against on the basis of characteristics such as gender or race than gender, while male colleagues were able to achieve the same academic results. In addition, the fact that women are given the same burden as men in teaching, combined with women's family responsibilities, leads to a decline in opportunities for men in the field of research[44].

Summarizing the above points, the following conclusions and suggestions can be made within this paragraph:

First, violence and psychological harassment against women during the COVID-19 pandemic had a negative impact on women's reproductive health through an increase in women's access to psychiatric and psychologist services, as well as a sharp increase in pregnancies;

Second, it is proposed to digitize the current procedure for issuing protection orders to women during the pandemic and to reduce the 24-hour ordering period to 12 hours by examining the victim's living conditions. This procedure provides that after consideration of the issue of the order by the inspector, the basic information on the protection order is 
automatically sent to the mobile phone of the land in the form of SMS-notification.

Third, the use of the Internet in the search, reception, transmission, production and dissemination of information in Uzbekistan during the pandemic has changed the guarantees of certain constitutional rights. Therefore, in order to support women's entrepreneurship, it is proposed to develop a Concept for Improving Women's Internet Literacy.

Fourth, in the context of a pandemic, it is advisable to train women in the first place in order to ensure their employment. In this regard, it is expedient to improve the practice of financing socially useful projects through targeted social ordering to non-governmental non-profit organizations.

Fifth, Women's Entrepreneurship Centers have been established in all regions of Uzbekistan. These centers provide practical assistance to about 28,000 women in entrepreneurship, crafts, retraining, employment [45]. In our opinion, it is expedient to include the concept of "women entrepreneurs" in the draft law "On Small Business and Private Entrepreneurship."

\section{REFERENCES}

1. https://cbu.uz/upload/iblock/dbd/Istem ol-kayfiyati.pdf

2. https://news.un.org/ru/story/2021/03/1 398112

3. Мжельская А. С. Механизмы международно-правового регулирования межличностного насилия и гендерного неравенства в период пандемии COVID-19//Вопросы российской юстиции. - 2020. - №. 9.

4. URL:

https://www.gazeta.uz/uz/2020/09/09/ un-women/

5. https://news.un.org/ru/story/2021/01/13 95342

6. URL:

https://www.gazeta.uz/uz/2020/09/03/ ayollar/

7. https://news.un.org/ru/story/2021/01/13 95342

8. van Wormer, K. Restorative Justice as Social Justice for Victims of Gendered Violence: A Standpoint Feminist Perspective. [Текст] // Social Work of Oxford Academic. — 2009. - April. vol. 54, iss. 2. - P. 107-115.

9. Пресс-релиз: Международная онлайн-конференция в Казахстане посвящена предотвращению насилия в отношении женщин и доступу женщин к правосудию // https://eca.unwomen.org/ru/news/stor ies/2020/11/intl-gathering-in-

kazakhstan-spotlights-prevention-ofviolence-against-women-and-accessto-justice

10. The United Nations Development Programme. Gender-based violence and COVID-19 [Электронный ресурс] // URL: https://goo.su/2ihg.

11. de Paz C. et al. Gender dimensions of the COVID-19 pandemic. - 2020.

12. Alon T. M. et al. The impact of COVID-19 on gender equality. - National Bureau of economic research, 2020. - №. w26947.

13. Adams R. B. Gender equality in work and Covid-19 deaths //Covid Economics. $-2020 .-$ №. 16. - C. 23-60. 
14. Pinho-Gomes A. C. et al. Where are the women? Gender inequalities in COVID19 research authorship //BMJ Global Health. - 2020. - T. 5. - №. 7. - C. e002922.

15. Power K. The COVID-19 pandemic has increased the care burden of women and families //Sustainability: Science, Practice and Policy. - 2020. - T. 16. - №. 1. - C. 67-73.

16. Ragasa C., Lambrecht I. COVID-19 and the food system: setback or opportunity for gender equality? //Food security. - 2020. - T. 12. - №. 4. C. 877-880.

17. Malisch J. L. et al. Opinion: In the wake of COVID-19, academia needs new solutions to ensure gender equity //Proceedings of the National Academy of Sciences. - 2020. - T. 117. - №. 27. C. $15378-15381$

18. Collins $C$. et al. COVID-19 and the gender gap in work hours //Gender, Work \& Organization. - 2021. - T. 28. C. 101-112.

19. Fortier N. COVID-19, gender inequality, and the responsibility of the state //International Journal of Wellbeing. 2020. - T. 10. - №. 3 .

20. d'Orville H. COVID-19 causes unprecedented educational disruption: Is there a road towards a new normal? //Prospects. - 2020. - T. 49. - C. 11-15.

21. Czymara C. S., Langenkamp A., Cano T. Cause for concerns: gender inequality in experiencing the COVID-19 lockdown in Germany //European Societies. 2020. - C. 1-14.

22. Gabster B. P. et al. Challenges for the female academic during the COVID-19 pandemic //The Lancet. - 2020. - T. 395. - №. 10242. - C. 1968-1970.
23. Cui R., Ding H., Zhu F. Gender inequality in research productivity during the COVID-19 pandemic //arXiv preprint arXiv:2006.10194. - 2020.

24. Oleschuk $M$. Gender equity considerations for tenure and promotion during COVID-19 //Canadian Review of Sociology. -2020.

25. Мжельская А. С. МЕХАНИЗМЫ МЕЖДУНАРОДНО-ПРАВОВОГО РЕГУЛИРОВАНИЯ

МЕЖЛИЧНОСТНОГО НАСИЛИЯ И ГЕНДЕРНОГО НЕРАВЕНСТВА В ПЕРИОД ПАНДЕМИИ COVID-19 //Вопросы российской юстиции. 2020. - №. 9.

26. Абдурахимова Н. Ч. ВЛИЯНИЕ ПАНДЕМИИ COVID-19 HA ИЗМЕНЕНИЕ РОЛИ ЖЕНЩИН В ЭКОНОМИЧЕСКОЙ ДЕЯТЕЛЬНОСТИ ТАДЖИКИСТАНА //Экономика Таджикистана. - 2020. - №. 3. - С. 5457.

27. Алиева К. ГЕНДЕРНОЕ РАВЕНСТВО ВО ВРЕМЯ ПАНДЕМИИ: ПРОБЛЕМА СЕМЕЙНО-БЫТОВОГО НАСИЛИЯ //Review of law sciences. - 2020. - №. 2.

28. Грудинин Н. С. Пути укрепления гарантий права на здоровье в условиях пандемии COVID-19 //Актуальные проблемы современных общественных наук в условиях вызовов мировой пандемии COVID-19. - 2020. - С. 35-42.

29. Мжельская А. С. СлОЖнОСТь РЕАЛИЗАЦИИ КОНСТИТУЦИОННОГО ПРИНЦИПА ГЕНДЕРНОГО РАВЕНСТВА В УГОЛОВНОМ ПРАВЕ В СОВРЕМЕННОЙ РОССИИ //ВопРОСЫ российской юстиции. - 2020. - №. 10. 
30. Калабихина И. Е., Ребрей С. М. ДОМАШНИЙ ТРУД ВО ВРЕМЯ ПАНДЕМИИ: ОПЫТ РОССИИ //Женщина в российском обществе. 2020. - №. 3. - C. 65-77.

31. URL: https://www.minjust.uz/uz/presscenter/news/99071/?print=Y

32. URL: https://yuz.uz/news/samarqanddaayolni-ayovsiz-kaltaklash-bilan-bogliqholat-nazoratga-olingan

33. Евсиков Кирилл Сергеевич Право граждан на доступ к услугам связи как средство реализации права на доступ к информации // Известия ТулГУ. Экономические и юридические науки. 2017. №1-2. URL: https://cyberleninka.ru/article/n/pravograzhdan-na-dostup-k-uslugam

34. Khotkina Z. A. et al. На пути к цифровому гендерному равенству //Женщина в российском обществе. 2018. - №. 3. - C. 5-13.

35. Gurumurthy A., Chami N. Gender equality in the information society //Bangalore: IT for Change. - 2014.

36. Gender Gap in Mobile Phone Ownership in the Developing World. Source: GSMA, 2020.

37. https://kun.uz/80719830

38. https://uza.uz/uz/posts/kamba-allikniis-artirishning-yangi-mekhanizmiyaratilmo-da-14-10-2020

39. https://sputniknewsuz.com/society/20201003/15109451/zbe kistonda-khotin-izlar-uchun-ishonchtelefoni-ishga-tushirilmoda.html

40. https://sputniknewsuz.com/society/20201003/15109451/zbe kistonda-khotin-izlar-uchun-ishonchtelefoni-ishga-tushirilmoda.html
41. Сергиенко Н. С. Социальная политика в условиях пандемии: опыт зарубежных стран //ББК 60.5 В57. 2020. - C. 174.

42. https://www.imemo.ru/news/events/t ext/mnogostoronniy-otvet-kanadi-napandemiyu-covid-19

43. Балашова А. С. Доступ к правосудию для женщин //потенциал инновационного развития российской федерации в новых геополитических условиях. - 2020. C. 155-157.

44. Malisch J. L. et al. Opinion: In the wake of COVID-19, academia needs new solutions to ensure gender equity //Proceedings of the National Academy of Sciences. - 2020. - T. 117. - №. 27. C. $15378-15381$.

45. https://strategy.uz/index.php?news=11 03

46. Musaev, B., 2017. The importance and pecularity of legal regimes applying to the subjects of labour relations in international private law. Review of law sciences, 1(1), p.16. 